\title{
Young Consumers' Intention Towards Future Green Purchasing in Malaysia
}

\author{
Muhammed Abdullah Sharaf \\ Othman Yeob Abdullah School of Business, Universiti Utara Malaysia \\ 06010, Kedah, Malaysia
}

Tel: 60-1-4238-8129 E-mail: mu21shi@yahoo.com

Filzah Md Isa (Corresponding author)

College of Business, Universiti Utara Malaysia

06010, Kedah, Malaysia

E-mail: filzah@uum.edu.my

Khalid Al-Qasa (Corresponding author)

College of Business, Universiti Utara Malaysia

06010, Kedah, Malaysia

E-mail: Khaled20767@yahoo.com

Received: Sep. 18, 2014 Accepted: December 21, 2014 Published: February 1, 2015

doi:10.5296/jmr.v7i2.6998 URL: http://dx.doi.org/10.5296/jmr.v7i2.6998

\begin{abstract}
Green marketing is all about marketing products that are considered environmentally safe. The purpose of this study is to examine the influence of price, time, and eco-label, on the intention of future green products purchasing among young Malaysian. In this study 250 questionnaires were distributed. The data was analyzed using reliability test, normality, correlation analysis, and multiple regressions. The results of this study showed that price, and time have a significant relationship with young consumers' intention to purchase green products, however, eco-label had no influence on consumers' intention to purchase green
\end{abstract}


products. This research brings a better understanding on young consumers' intention towards future green purchasing in Malaysia.

Keywords: Green Marketing, Green Purchasing, Consumer's Intention, Malaysia 


\section{Introduction}

Green marketing refers to marketing products that are categorized as environmentally safe products. Green marketing involves several activities that are associated with products modification, their packaging process, as well as advertising these products (Mishra \& Sharma, 2010). The concept of green marketing is also related to the concept of holistic marketing, where several activities are included such as producing, marketing, and consuming the products, as well as disposing the product in an environmentally safe way. Over the years, more and more consumers have started to recognize how their behavior is affecting the environment. Many evidences in recent studies are showing how consumers avoid some product and choose other depending on how these products are harmful to the environment of safe to its nature (Laroche, Bergeron, \& Barbaro-Forleo 2001).

Green consumers seem to be internally controlled more than regular customers as they have a strong belief that every individual has the ability to contribute positively to the environment. Hence, they feel that protecting the environment is everyone's job and individuals shouldn't rely entirely on environmentalists, governments, scientists and businesses. They tend to be more open minded and less dogmatic toward new ideas and products. This open-mindedness drives them to support green products readily (Shamdasani, Chon-Lin, and Richmond, 1993; Peattie, 2011).

Previous studies suggest that some people get involved in environmental behavior because they want to solve the environmental issues and to appear to others as role models (Hallin, 1995; Gan, Wee, Ozanne \& Kao, 2008), and due to their belief that they have the ability to protect the environment. Even though such studies give a vision of what can motivate consumers to be involved in green behaviors, the possibility that these motivations can result in having green consumers is not confirmed specially when the topic comes to green product purchasing behavior.

According to Golnaz, Phuah, Zainalabidin, and Mad Nasir (2013), the green concept is novel to Malaysian consumers although many campaigns that encourage people to go green have been carried out from time to time. The green products' market in Malaysia is still at its infancy stage, little knowledge about patterns of consumers' green consumption in Malaysia is available, however introducing green food in the Malaysian market besides the high health consciousness that Malaysia consumer have brought an interesting topic on the behavior of consumers' food purchasing (Worthington \& Patton, 2005).

Malaysian consumers have a different understanding about green products and the going green concept than consumers in western countries. People in the western countries view green products as these products that cause less harm to the environment and produce less pollution, while Malaysian understand green products as "specialty high price products" and tend to feel that these types of products are specific to a certain group of consumers (Shahnaei, 2012). Malaysian consumers spend a high percentage of their household income on groceries, food, and personal care items. 
ACNielsen suggested that on average, a Malaysian consumer spends MYR505 every month on groceries and food, however below have of these expenses go on fresh food such as fruits, vegetables and meat (Global Retail \& Consumer Study, 2009; 2010).

\section{Literature Review}

\subsection{Consumers’intention}

Purchase intention refers to individual's intention to purchase a particular brand which they select for themselves after performing some evaluations, there are several variables that could help in measuring purchasing intention such as brand, price and quality which will help in the actual purchasing activity in the future (Laroche, Kim \& Zhou, 1996; Hafeez \& Muhammad 2012). Having the intention to purchase a particular product requires an evaluation of other products in the market (Teng \& Laroche , 2007).

An individual's intention to purchase falls under the decision of the reason why this individual wants to purchase a particular brand. Concepts such as taking into consideration about something, purchasing a particular brand, and anticipating buying a specific product helps in scoping the intentions of purchasing (Porter, 1974). Furthermore, Porter (1974) explained that a consumers' intention to buy a specific product does not get effected simply with his attitude towards that product, but also effects his future decisions to buy other brands that are set in his consideration.

Ghosh (1990) took a new approach by combining several studies related to purchasing behavior with other studies that focus on consumers' decision-making processes. He then found that when a consumer selects a particular product, his final decision relies entirely on his intention (Chen, 2008). Therefore, many marketers believe that one of the best methods that can be used to predict consumers' purchases in the future is to understand their current purchasing intention, in addition Sudhir and Talukdar (2004), Jaafar and Lalp (2011) argued that there is a positive relationship between consumers' purchase intention and their quality perception. Zeithaml (1988) and Tsiotsou (2005) added that an individual's purchase intention is always affected by many different factors such as quality perception, objective price, and value perception.

\subsection{Price}

Some authors such as (Lisa, 2004) discussed the unfair pricing topic which can simply be defined as charging consumers with high prices compared to the expected or supposed price, or charging fictional prices. Marketers found that even though some consumers may strongly support protecting the environment, they still show an extreme price sensitivity when they intend to buy green products (Mainieri, Barnet, Valdero, Unipan, \& Oskamp, 1997; Kaufmann, Panni, \& Orphanidou 2012).

McKenzie-Mohr (2000) stated that the fact that recycled-content products could have a high price, this created an obstacle among Washington residents to purchase these products. These studies have also reported that in different cases, marketers usually charge very high prices for products that are environmentally friendly in a way that is clearly unjustified and 
non-transparent. Such an attempt leads to discourage and demotivation among consumers who participate in green purchasing behavior.

\subsection{Time}

According to Engel, Miniard and Blackwell (1995) consumers prefer to purchase products which will save them time when they search for them. Furthermore, Salgado-Beltrán, Espejel-Blanco, and Beltrán-Morales (2012) mentioned that consumers can show more interest in purchasing green products if those green goods were available and could be found easily. Green markets in Malaysia are not easily found and can't be accessed as fast as regular markets (Shahnaie, 2012).

Many empirical evidence shows that when consumers find difficulty to locate environmentally friendly products this occurs due to information lack (Brown \& Wahlers, 1998; Kaufmann et al., 2012). Byrne, Toensmeyer, German, \& Muller (1991), Davies, Titterington, \& Cochrane (1995), and Ahmad and Juhdi (2008) indicated that when there is a lack of organic food and green products availability in stores, it could be considered as a major obstacle that consumers could face during their purchasing process. Availability means the level of difficult or ease to find or to consume a specific product. Vermeir and Verbeke (2004) suggested that many consumers are motivated to purchase green products however this motivation doesn't translate in their actual purchasing behavior when green products availability is low. One main reason of consumers' environmental lagging behind the pro-environmental behavior is their low availability and weak marketing for green products.

\subsection{Eco-label}

Marketers are increasingly utilizing environmental labels in order to promote the products' identification (D'Souza, Taghian, \& Lamb, 2006). Most of the studies that are concerned with eco-labels are searching of methods that could help making these products effective in the purchasing behavior of consumers that are associated with environmental safe products (D'Souza et al., 2006). Rashid (2009) stated that the eco-label awareness has a positive impact with green products knowledge and consumers' purchase intention. He also added that eco-labels of green products are useful instruments to attract consumers and inform them about the effects of their purchasing decision and the environment.

To the current data, more than 30 different green label schemes are available around the world. Asian countries introduced their own eco-labeling schemes (Rashid, 2009). The green label of Malaysia was committed in 1996, and started by the Standards and Industrial Research Institute of Malaysia (SIRIM). During that time, recycled paper ware, non-toxic plastic packaging material, energy conservation, biodegradable cleaning agents, degradable, electronic equipment and hazardous metal-free electrical and agricultural products were categorized and linked to the scheme of eco-labeling that was drafted by SIRIM (Rahber \& Wahid, 2010).

Besides Rashid's (2009) study, Grankvist, Dahlstrand and Biel (2004) indicated that young respondents, women, and graduates show a more positive attitude towards products that are eco-labeled. Loureiro and Lotade (2005) mentioned that many consumers specifically in 


\section{Macrothink}

Journal of Management Research

ISSN 1941-899X

2015, Vol. 7, No. 2

developed countries are willing to pay more eco-labeled products. Some studies suggested that despite the labels' function which consumers can recognize, it still doesn't lead them automatically to make decisions that support green purchasing (Leire \& Thidell, 2005).

\subsection{Framework}

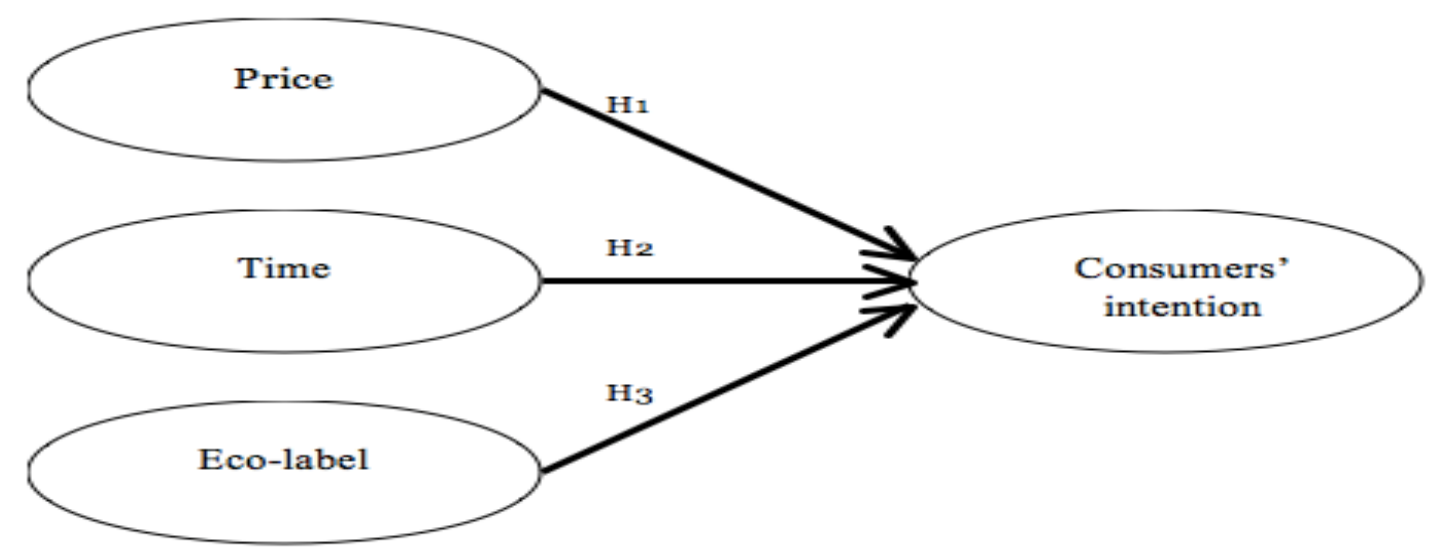

Figure 1. Theoretical Framework

\section{Methodology}

\subsection{Research respondents}

For the purpose of this research, the data is collected through the local students of Universiti Utara Malaysia, there are two reasons for choosing the local students as respondents; first reason due to the similarity of students' characteristics, while the second reason is that those students can be a perfect sample for young consumers as their ages range is between 18 and 25.

Table 1. Demographic Profile of Respondents

\begin{tabular}{|l|l|l|}
\hline \multicolumn{1}{|c|}{ Demographics } & \multicolumn{1}{|c|}{ Categories } & \multicolumn{1}{c|}{ Frequency } \\
\hline Gender & Male & 70 \\
& Female & 121 \\
\hline Age & Below 18 & 1 \\
& Between 18-23 & 167 \\
& Between 23-27 & 23 \\
\hline Ethnicity & Malay & 94 \\
& Chinese & 73 \\
& Indian & 17 \\
\hline
\end{tabular}

Table 1 illustrates the respondents' demographic profile. The majority of respondents are aged between 18 years old and 23 years old with a percentage of $87 \%$ and this result is expected as the majority of students in Universiti Utara Malaysia range within this age 
category. Only one respondent is under 18 years old, and 23 of them are between the age of 23 and 27 making a total of $12 \%$ of the sample. Regarding the respondents' gender, a lower number of male ( 70 or $36.6 \%$ ) compared to $(121$ or $63.4 \%$ ) of females represent the students in Universiti Utara Malaysia. This shows that there are more female students in the university compared to male. In terms of ethnicity, the majority of respondents are Malay (94 or 49.2\%), followed by Chinese (73 or 38.2\%), Indian (17 or $8.9 \%$ ) and others (7 or 3.7\%).

\subsection{Reliability Test}

A reliability analysis was run onto the dependent and independent variables, which consisted of price, time, and eco-label in order to find the reliability of each variable using Cronbach's alpha. Table 4.2 shows the alpha value for the six independent variables.

Table 2. Cronbach's Alpha Value for Dependent and Independent Variables

\begin{tabular}{|l|l|l|}
\hline \multicolumn{1}{|c|}{ Type of variable } & \multicolumn{1}{|c|}{ Variables } & Cronbach's alpha value \\
\hline Dependent variable & Intention to purchase green products & .836 \\
Independent & Price of green products & .735 \\
variables & Time spent to find green products & .723 \\
& Eco-label of green products & .814 \\
\hline
\end{tabular}

From the table above, we can notice that the cronbach's alpha for the dependent variable is .836 , while for the independent variables range between .723 and .836 , hence the mentioned cronbach's alpha values indicates that the reliability of all the variables together as well as the dependent and independent variables separately were considerably reliable and acceptable as suggested by Sekaran (2003).

\subsection{Correlation Analysis}

Table 3 shows the inter-correlational results among the studied variables. The results of the correlation analysis proved that a relationship between the dependent variable and the independent variable exists. Starting with the intention to purchase green products, it is shown that there is a significant and positive relationship with all the independent variables namely price of green products $(\mathrm{r}=0.500)$, time spent to purchase $(\mathrm{r}=0.850)$, and eco-label of green products $(\mathrm{r}=0.457)$, at $\mathrm{p}<0.01$.

Table 3. Pearson Correlations of Study Variables $(\mathrm{N}=191)$

\begin{tabular}{|l|l|l|l|l|}
\hline & \multicolumn{1}{|c|}{ Intention } & \multicolumn{1}{c|}{ Price } & \multicolumn{1}{c|}{ Time } & Eco-label \\
\hline Intention & 1 & & & \\
\hline Price & $.500^{* *}$ & 1 & & \\
\hline Time & $.850^{* *}$ & $.755^{* *}$ & 1 & \\
\hline Eco-label & $.457^{* *}$ & $.479^{* *}$ & $.476^{* *}$ & 1 \\
\hline
\end{tabular}

** Correlation is significant at the 0.01 level (2-tailed). 
From this analysis, it can be concluded that time exert the strongest and have a significant positive correlation with the intention $(\mathrm{r}=0.850)$. The overall correlation coefficient values of the study variables range between 0.457 and $8.50(\mathrm{p}<0.01)$, thus the results show a strong association between the dependent and independent variables.

\subsection{Regression Analysis}

Table 4.7 gives a summary for the hypothesis and indicates which variable has an influence on young consumers' intention to purchase green products in Malaysia as the coefficients for each model is tested. Two of the independent variables are significant with p-value less than $.05(\mathrm{p}<.05)$ which are: price, and time while the result shows that eco-label does not influence young consumers' intention to purchase green products in the future.

Table 4.7. Hypothesis Summary

\begin{tabular}{|l|l|l|}
\hline \multicolumn{1}{|c|}{ Hypothesis } & P & \\
\hline $\begin{array}{l}\text { H1: Price has a significant influence on young consumers' intention } \\
\text { towards green purchasing in Malaysia }\end{array}$ & .000 & Supported \\
\hline $\begin{array}{l}\text { H2: Time has a significant influence on young consumers' intention } \\
\text { towards green purchasing in Malaysia. }\end{array}$ & .000 & Supported \\
\hline $\begin{array}{l}\text { H3: Eco-label has a significant influence on young consumers' intention } \\
\text { towards green purchasing in Malaysia. }\end{array}$ & .134 & Not supported \\
\hline
\end{tabular}

\section{Discussion}

Taking the three dimensions that were studied in this research; price, time, and eco-label, the results that came out showed that only two of the studied variables had a direct influence on young consumers' intention to purchase green products in Malaysia which are price, and time. However, eco-label did not show any direct influence.

Price showed a significant influence on young consumers' intention to purchase green products. The importance of studying price came from the general agreement by different authors that generally green products could have a high price and this could be an obstacle for consumers (Mc Kenzie-Mohr, 2000), price will always be an indicator of consumers intention to purchase different products including green products, that's because almost all consumer are always price sensitive. The issue of overpricing green products has been discussed in many researches such as Mainieri, Barnet, et al,. (1997) and Kaufmann, et al,. (2012), and no different findings came out from the one that is presented in this study despite the demographic of the respondents. The results generated from this study proved that such a factor could influence young consumers' intention to whether or not they should purchase green products.

Time also had a significant influence on young Malaysians' intention to purchase green products in the future and this result is consistent with the study that Vermeir and Verbeke (2004) made which suggested that majority of consumers are encouraged to purchase green products however this encouragement doesn't translate in their actual purchasing behavior 
when green products availability is low. Different consumers are looking for ways to save their time such as buying online. Products that are not easily found will always be consumers' last choice.

\section{Limitation}

This study was only conducted on students, however there are other young consumers who are not students and might by working and hence could have different intentions due to their ability to purchase than those who are more educated. Another limitation is that this study was conducted on students in Universiti Utara Malaysia; which is located in a green supporting environment and is a public university. Other students in other universities could come out with different results as some universities are located in more urban locations which could have an effect on their perspective on the environment, while other private universities contain young consumers who probably would have a stronger purchasing power as well as a different background. Therefor the findings of this study are unable to be generalized to all population of young consumers in Malaysia. Furthermore, this study examined only three variables that could influence young consumers' intention to purchase green products in Malaysia which are price, time, and eco-label; however these variables are not the only determinants. There are many purchasing considerations for young consumer, which could help in determining if they would have the intention to purchase green products.

\section{Contribution}

This current study's findings provide evidence on what influences young consumers' intention towards purchasing green products in Malaysia. This research focuses on young consumers despite their ability to actually purchase the green products; instead, this research studies their intention to make future green purchases. The results of this study helps in filling the gap of previous literatures by proving the significance of price, time, and social influence on young consumers' intention to purchase green products.

Furthermore, this study is significant for firms that offer green products. It suggests those firms to provide green products with better prices, and make consumers spend less time to find green products by making them available more in different stores. Understanding young consumers' intention to purchase these green products helps firms plan sustainable strategies to target those consumers.

Policy makers could gain some benefits from this research as it can help them decide on what approaches they should follow in order to enhance young Malaysian to support green products. They could also play a role by enforcing less tax on green products in order to encourage young consumers to purchase these products and they could raise different campaigns to bring more awareness to different people.

\section{Conclusion}

From this study we can understand the importance of green marketing, green products, and green purchasing. The main predictors of young consumers' intention to purchase green products in the future are price, and time. Price has been and will always be a key factor in 
consumers' purchasing intention, consumers are always price sensitive and with high competency in the market green products should be offered in lower prices in order to attract young consumers to purchase them. Time is another important factor as consumers have less and less time to spend in purchasing different items, they always tend to find faster and easier ways to buy their desired products and with green products being scarce in the market young consumers intention will reflect in accordance.

In the other hand eco-label showed that it doesn't have a significant influence on young consumers' intention towards future green purchasing, and this reveals many facts of how green marketing is operating and what steps should be taken to encourage more young consumers to go green.

\section{References}

Ahmad, S. N. B., \& Juhdi, N. (2008). Consumer's Perception And Purchase Intentions Towards Organic Food Products: Exploring The Attitude Among Malaysian Consumers. In 16th Annual Conference on Pacific Basin Finance, Economics, Accounting and Management, Brisbane, Australia.

Brown, J. D., \& Wahlers, R. G. (1998). The environmentally concerned consumer: an exploratory study. Journal of Marketing Theory and Practice, 39-47.

Byrne, P. J., Toensmeyer, U. C., German, C. L., \& Muller, H. R. (1991). Analysis of consumer attitudes toward organic produce and purchase likelihood. Journal of Food Distribution Research, 22(2), 49-62.

Chen, K. (2008). A study of the relationship between UK consumers purchase intention and store brand food products--Take Nottingham city consumers for example (Doctoral dissertation, University of Nottingham).

D'Souza, C., Taghian, M., \& Lamb, P. (2006). An empirical study on the influence of environmental labels on consumers. Corporate Communications: An International Journal, 11(2), 162-173. http://dx.doi.org/10.1108/13563280610661697

Davies, A., Titterington, A. J., \& Cochrane, C. (1995). Who buys organic food?: A profile of the purchasers of organic food in Northern Ireland. British Food Journal, 97(10), 17-23. http://dx.doi.org/10.1108/00070709510104303

Engel, J. F., Blackwell, R. D., \& Miniard, P. W. (1995). Consumer behavior, 8th. New York: Dryder.

Gan, C., Wee, H. Y., Ozanne, L., \& Kao, T. H. (2008). Consumers' purchasing behavior towards green products in New Zealand. Innovative Marketing, 4(1), 93-102.

Ghosh, M. K. (1990). Markov decision processes with multiple costs. Operations Research Letters, 9(4), 257-260. http://dx.doi.org/10.1016/0167-6377(90)90070-L

Golnaz. R., Phuah, K.T. Zainalabidin, M., \& Mad Nasir, S., (2013). Going green: Survey of perceptions and intentions among Malaysian consumers. International Business and 
Management, 6(1), 104-112.

Grankvist, G., Dahlstrand, U., \& Biel, A. (2004). The impact of environmental labelling on consumer preference: Negative vs. positive labels. Journal of Consumer Policy, 27(2), 213-230. http://dx.doi.org/10.1023/B:COPO.0000028167.54739.94

Hafeez, S., \& Muhammad, B. (2012). The Impact of Service Quality, Customer Satisfaction and Loyalty Programs on Customer's Loyalty: Evidence from Banking Sector of Pakistan. International Journal of Business and Social Science.

Hallin, P. O. (1995). Environmental concern and environmental behavior in Foley, a small town in Minnesota. Environment and Behavior, 27(4), 558-578. http://dx.doi.org/10.1177/0013916595274006

Jaafar, S. N., \& Lalp, P. E. (2011). Consumers' Perceptions, Attitudes and Purchase Intention towards Private Label Food Products in Malaysia.

Kaufmann, H. R., Panni, M. F. A. K., \& Orphanidou, Y. (2012). Factors Affecting Consumers' Green Purchasing Behavior: An Integrated Conceptual Framework. The AMFITEATRU ECONOMIC journal, 14(31), 50-69.

Laroche, M., Bergeron, J., \& Barbaro-Forleo, G. (2001). Targeting consumers who are willing to pay more for environmentally friendly products. Journal of consumer marketing, 18(6), 503-520. http://dx.doi.org/10.1108/EUM0000000006155

Laroche, M., Kim, C., \& Zhou, L. (1996). Brand familiarity and confidence as determinants of purchase intention: an empirical test in a multiple brand context. Journal of business Research, 37(2), 115-120. http://dx.doi.org/10.1016/0148-2963(96)00056-2

Leire, C., \& Thidell, Å. (2005). Product-related environmental information to guide consumer purchases-a review and analysis of research on perceptions, understanding and use among Nordic consumers. Journal of Cleaner Production, 13(10), 1061-1070. http://dx.doi.org/10.1016/j.jclepro.2004.12.004

Lisa, A., 2004. Is it unfair pricing?. Tire Business, 22(14), p. 15

Loureiro, M. L., \& Lotade, J. (2005). Do fair trade and eco-labels in coffee wake up the consumer conscience? Ecological Economics, 53(1), 129-138. http://dx.doi.org/10.1016/j.ecolecon.2004.11.002

McKenzie-Mohr, D. (2000). Quick reference: community-based social marketing. Retrieved March, 26, 2002.

Mainieri, T., Barnett, E. G., Valdero, T. R., Unipan, J. B., \& Oskamp, S. (1997). Green buying: The influence of environmental concern on consumer behavior. The Journal of social psychology, 137(2), 189-204. http://dx.doi.org/10.1080/00224549709595430

Mishra, P., \& Sharma, P. (2010). Green marketing in India: Emerging opportunities and challenges. Journal of Engineering, Science and Management Education, 3, 9-14. 
Peattie, K. (2011). Towards sustainability: achieving marketing transformation-a retrospective comment. Social Business, 1(1), 85-104. http://dx.doi.org/10.1362/204440811X570581

Porter, M. E. (1974). Consumer behavior, retailer power and market performance in consumer goods industries. The Review of Economics and Statistics, 56(4), 419-436. http://dx.doi.org/10.2307/1924458

Rahbar, E., \& Wahid, N. A. (2010). The Malaysian Consumer and the Environment: Purchase Behavior. Global Business and Management Research: An International Journal, 2(4), 323-336.

Rashid, N. R. N. A. (2009). Awareness of eco-label in Malaysia's green marketing initiative. International Journal of Business and Management, 4(8), P132. http://dx.doi.org/10.5539/ijbm.v4n8p132

Salgado-Beltrán, L., Espejel-Blanco, J. E., \& Beltrán-Morales, L. F. (2012). Marketing Mix Influencing Organic Foods Purchase of Mexican Consumers. In MIC 2012: Managing Transformation with Creativity; Proceedings of the 13th International Conference, Budapest, 22-24 November 2012 [Selected Papers] (pp. 993-1006). University of Primorska, Faculty of Management Koper.

Shahnaei, S. (2012). The Relationship Between Demographic Characteristics And Green Purchasing Of Malaysian Consumers. Interdisciplinary Journal Of Contemporary Research In Business, 4(3).

Shamdasani, P., Chon-Lin, G. O., \& Richmond, D. (1993). Exploring green consumers in an oriental culture: role of personal and marketing mix factors. Advances in consumer research, 20(1), 488-493.

Sudhir, K., \& Talukdar, D. (2004). Does store brand patronage improve store patronage? Review of Industrial Organization, 24(2), 143-160. http://dx.doi.org/10.1023/B:REIO.0000033353.52208.ba

Teng, L., \& Laroche, M. (2007). Building and testing models of consumer purchase intention in competitive and multicultural environments. Journal of Business Research, 60(3), 260-268. http://dx.doi.org/10.1016/j.jbusres.2006.09.028

Tsiotsou, R. (2005). Perceived quality levels and their relation to involvement, satisfaction, and purchase intentions. Marketing Bulletin, 16(4), 1-10.

Vermeir, I., \& Verbeke, W. (2004). Sustainable food consumption: Exploring the consumer attitude-behaviour gap. Ghent University, WP, 4, 268.

Worthington, I. \& Patton, D. (2005). Strategic intent in the management of the green environment within SMEs. Long Range Planning, 38, 197-212. http://dx.doi.org/10.1016/j.1rp.2005.01.001

Zeithaml, V. A. (1988). Consumer perceptions of price, quality, and value: a means-end model and synthesis of evidence. The Journal of Marketing, 2-22. http://dx.doi.org/10.2307/1251446 


\section{Copyright Disclaimer}

2015, Vol. 7, No. 2

Copyright for this article is retained by the author(s), with first publication rights granted to the journal.

This is an open-access article distributed under the terms and conditions of the Creative Commons Attribution license (http://creativecommons.org/licenses/by/3.0/). 